\title{
PEMBERDAYAAN KELOMPOK IBU-IBU PKK DI DUSUN GULON, NANGSRI DAN CANDI KECAMATAN PUNDONG, BANTUL MELALUI OLAHAN MAKANAN BERBAHAN DASAR MOCAF
}

\author{
Isana Arum Primasari \\ Universitas Ahmad Dahlan Yogyakarta \\ E-mail: i_prisa@yahoo.com
}

\begin{abstract}
Abstrak
Pundong merupakan salah satu kecamatan yang berada di wilayah Kabupaten Bantul merupakan lokasi pelaksanaan PPM bekerjasama dengan mahasiswa KKN. Potensi wilayah Pundung sangat banyak dan beberapa sudah dimanfaatkan dengan baik oleh warga Pundong. Berbagai kegiatan telah dilaksanakan melalui program penyuluhan, pelatihan hingga pendampingan kepada warga. Kegiatan pemberdayaan masyarakat yang dilaksanakan tersebut dalam rangka pemanfaatan potensi lokal yang cukup banyak dan belum dipergunakan dengan baik. Program ini juga mendampingi kegiatan keagamaan dalam rangka meningkatkan keimanan dan kenyamanan beribadah ummat. Fokus dari kegiatan ini adalah pada potensi lokal yaitu beras hitam yang diolah menjadi berbagai olahan pangan dan minuman serta masker wajah juga membawakan program MPM PP Muhammadiyah dalam hal sosialisasi serta praktek olahan pangan menggunakan tepung Mocaf. Metode pelaksanaan program PPM meliputi: pendidikan masyarakat, difusi teknologi dan praktek langsung. Dampak dari kegiatan program PPM di Dusun Gulon, Dusun Nangsri dan Dusun Candi Kecamatan Pundong, Kabupaten Bantul dapat diperoleh manfaat: 1) tercipta kesadaran ummat tentang hidup bersih dan sehat, 2) peningkatan pengetahuan warga Pundong tentang pemanfaatan potensi wilayah, 3) masyarakat terampil dalam berbagai program pemanfaat bahan-bahan tidak terpakai, 4) tersedianya taman bacaan di masjid untuk mencerdaskan ummat.
\end{abstract}

Kata kunci: pemberdayaan, Pundong, Beras Hitam, Mocaf.

\begin{abstract}
Pundong is one of the districts in Bantul Regency is the location of the PPM implementation in cooperation with the student service learning. Potential Pundung area very much and some have been put to good use by residents Pundong. Various activities have been implemented through training programs, training to mentoring to Waraga in these hamlets for one month. Community development activities undertaken in the framework of the utilization of local potential is large enough and has not been used properly. The program also assists religious activities in order to improve the comfort of faith and worship of the Ummah. The focus of these activities is on the local potential that black rice is processed into a variety of processed food and beverages as well as face masks also bring MPM PP Muhammadiyah program in terms of socialization and the practice of using flour Mocaf processed food. PPM program implementation methods include: public education, the diffusion of technology and practice. The impact of program activities PPM in Hamlet Gulon, Hamlet Nangsri and Hamlet Temple Pundong, Bantul can be obtained benefits: 1) create awareness of community about clean and healthy life, 2) improving the knowledge of citizens Pundong about exploiting the potential of the region, 3) people skilled in various programs utilizing unused materials, 4) the availability of TBs in mosques to educate the community.
\end{abstract}

Keywords: empowerment, Pundong, Black Rice, Mocaf. 
Diterbitkan oleh Lembaga Pengabdian kepada Masyarakat

Universitas Ahmad Dahlan Yogyakarta

\section{A. PENDAHULUAN}

Pundong adalah sebuah kecamatan di Kabupaten Bantul, Provinsi Daerah Istimewa Yogyakarta. Kecamatan Pundong terletak di sebelah selatan Kabupaten Bantul dengan jarak kurang lebih 10 km serta jarak dari Ibukota Provinsi Daerah Istimewa Yogyakarta

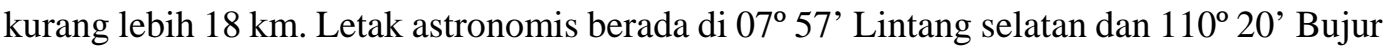
timur.

Kecamatan Pundong sungguh kaya akan makanan khas dan budaya, salah satunya di Desa Srihardono, lebih tepatnya di Dusun Nangsri. Di Dusun Nangsri telah dikembangkan industri rumahan yang memproduksi berbagai makanan yang terbuat dari singkong. Mie Des atau (Bakmie Pedas) yang terkenal, selain itu terdapat makanan khas lainnya seperti Abangan, kerupuk, mie pentil, dan pati aci.

Adapun potensi dari warga Pundong mayoritas di dusun Nangsri adalah mengelola home industry, seperti pengolahan singkong yang dijadikan tepung aci, miedes, mie pentil, abangan dan kerupuk. Berbagai hasil dari mengelola home industry adalah sebagai berikut:

1. Abangan dan Kerupuk

Abangan dan kerupuk merupakan beberapa produk yang banyak dihasilkan oleh industri rumahan di Dusun Nangsri. Kedua produk ini berasal dari tepung pati aci yang diolah oleh warga. Produk abangan dan kerupuk yang dihasilkan biasanya dijual sendiri oleh warga di pasar setempat ataupun guna memenuhi pesanan dari tempat lain. Abangan sendiri memiliki rasaasam, gurih dan pedas serta cara memasaknya digoreng. Sedangkan untuk kerupuk sendiri memiliki rasa gurih dan memiliki tekstur yang sama dengan kerupuk pada umumnya.

2. Meubel

Usaha meubel merupakan salah satu usaha yang dimiliki beberapa warga di RT 05 Dusun Nangsri, dimana usaha ini cukup besar dan sudah di pasarkan keluar kota dan khususnya di dusun ini sebagian dipergunakan untuk keperluan warga setempat, seperti fasilitas yang ada di joglo berupa meja dan rak buku itu langsung di produksi dari usaha meubel.

3. Miedes dan Mie Pentil

Miedes dan Mie Pentil merupakan beberapa produk olahan singkong yang dihasilkan di Dusun Nangsri. Kedua jenis mi ini pada dasarnya berasal dari bahan dasar yang sama dan diolah dengan cara yang sama. Yang membedakan kedua produk ini adalah sentuhan akhir saat proses pemotongan. Adonan setengah jadi bisa dimasukan ke dalam mesin pembentuk mi sederhana yang akan menghasilkan mi dengan diameter yang relatif lebih kecil yang dinamakan mie pentil; atau adonan mi dipotong kasar menggunakan pisau sehingga menghasilkan diameter yang relatif lebih besar yang dinamakan miedes.

4. Pati Aci ( Ketela Pohon )

Dibuat dengan cara memeras air saripati sumbernya, kemudian didiamkan atau diendapkan hingga didapati endapan yang terpisah dari airnya. Endapan ini yang kemudian dikeringkan dan didapatkan produk yang berupa tepung. Tepung yang terbuat dari pati jika dipegang dan digosokkan ke tangan akan terasa licin.

Kegiatan progam pengabdian kepada masyarakat ini dilaksanakan di 3 dusun yaitu Dusun Gulon, dusun Nangsri dan dusun Candi merupakan dusun didalam lingkup kecamatan Pundong, Kabupaten Bantul. Data singkat masing-masing dusun seperti kami uraian pada paragraf berikutini. 
Dusun Gulon terdiri dari 629 Jiwa yang mana terbagi menjadi 303 laki-laki dan 326 perempuan, dengan luas Dusun sekitar 32,5 ha.Mayoritas pekerjaan penduduk di Dusun Gulon adalah petani dan ada sebagian kecil bekerja sebagai PNS, industri rumahan, dll. Dusun Gulon adalah dusun yang sangat aktif, dalam artian di Dusun Gulon memiliki banyak program kegiatan mulai dari kegiatan ibu-ibu, bapak-bapak, sampai pemudanya dan setiap RT memiliki banyak perkumpulan, seperti arisan, pengajian rutin, koperasi simpan pinjam, dll.

Kegiatan remaja terbagi menjadi dua organisasi, yaitu remaja masjid dan pemuda Dusun. Disamping itu masih bayak lagi organisasi pemuda pada setiap RT disebut sebagai Sinoman. Ada juga yang melibatkan para petani, seperti kelompok tani dan ibu-ibu disebut ibu-ibu PKK.

Profil Pedukuhan Nangsri merupakan salah satu dusun dari tujuh belas dusun di Desa Srihardono, Kecamatan Pundong, Kabupaten Bantul. Dusun Nangsri terdiri dari lima Rukun Tetangga (RT) yang dihuni oleh 214 kepala keluarga secara keseluruhan. Jumlah penduduk laki-laki Dusun Nangsri sebanyak 403 jiwa sementara jumlah penduduk perempuan sebanyak 432 jiwa. Dari jumlah tersebut, terdapat 502 jiwa yang termasuk ke dalam angkatan usia produktif.

Dukuh Candi merupakan pedukahan yang terletak di Desa Srihardono, Kecamatan Pundong, Bantul. Dukuh Candi memiliki 7 Rukun Tetangga (RT) terbagi menjadi 4 kampungyang memiliki budaya yang berbeda- beda setiap kampung.Kampung di dukuh candi terdiri dari kampung Candi (RT 5,6,7), kampung Derso (2,3), kampung Dowi(RT 1) dan kampung Karang Monggang (RT 4).Jumlah kepala keluraga di dusun ini rata- rata 35 kepela keluraga untuk setiap RT. Sedangkan mata pencaharian utama masyrakat dusun candi adalah sebagai petani. Ada beberapa warga yang bekerja sebagai pegawai negeri, dosen, guru, wirausaha, dan buruh.

Pengolahan pertanian di Dusun Candi dikelola dengan manajemen yang baik kelompok tani Dusun Candi. Kelompok Tani Dusun Candi di ketuai oleh ketua RT 7 pak Sudarto. Pengelolaan penanaman dilihat dari kondisi cuaca dengan jenis tanaman yang harus ditanam di sepakati bersama anggota kelompok tani. Pengolahan pertanian mulai dari pembibitan, pemumukan sampai dengan panen di jadwalkan bersama anggota kelompok tani.

Salah satu potensil yang sangat menarik untuk dikembangkan di Dusun Candi di bidang pertanian yaitu produksi pupuk organik. Pupuk organik ini diproduksi olah salah satu petani yang ada di Dusun Candi berawal dari coba - coba. Pupuk organik yang dikembangkan adalah pupuk organik dari air kencing kelinci. Pupuk organik yang dihasilkan ini menghasilkan tanaman yang lebih bagus dan hasil panen yang lebih banyak. Untuk tanaman padi hasil yang didapatkan nasi dengan menggunakan pupuk organik ini lebih awet, akan tetapi beras yang dihasilkan berwana lebih gelap dari beras yang menggunakan pupuk kimia.

Pupuk organik ini di buat dari campuran air kencing kelinci dan beberapa dedaunan yang memiliki rasa pahit. Campuran ini kemudian di permentasikan sehingga menjadi pupuk organik. Pupuk organik ini dapat mengurangi hama, kandungan dedaunan yang memiliki rasa pahit menyebakan hama menjauhi tanaman. Satu botol pupuk organik ini digunakan untuk memberi pupuk 1 sawah. Dalam pemberian pupuk, pupuk organik dicampur dengan air.

Petani di Dusun Candi belum semua menggunakan pupuk organik ini sebagai alternatif pengganti pupuk kimia, karena keterbatasan produksi dari penegelola pupuk organik. Untuk air kencing kelinci didapatkan dari peternak kelinci yang ada di Babarsari. Produksi pupuk ini masih dikembangkan di rumah dan digunakan sendiri, kecuali ketika ada pesanan baru di perjual belikan. Karena keterbatasan alat pengujian sehingga pengelola 
Diterbitkan oleh Lembaga Pengabdian kepada Masyarakat

Universitas Ahmad Dahlan Yogyakarta

belum bisa memproduski pupuk secara masal. Selain itu, pengetahuan masyarakat yang kurang juga memepengaruhi kurangnya perkembangan pupuk organik ini.

\section{B. METODE PELAKSANAAN}

Untuk mencapai tujuan pemberdayaan ummat melalui program KKN di lingkungan PRM Warungboto dilakukan dengan melalui pendidikan masyarakat, difusi ilmu pengetahuan dan teknologi dan praktek langsung. Ringkasan metode pelaksanaan beserta jam kerja efektif mahasiswa (JKEM) tersaji pada tabel 1.

Tabel 1. Metode, Kegiatan, JKEM dan keterlibatan mahasiswa

\begin{tabular}{|c|c|c|c|c|}
\hline No & Metode & Kegiatan & JKEM & $\begin{array}{l}\text { Jumlah mhs } \\
\text { terlibat }\end{array}$ \\
\hline \multirow[t]{3}{*}{1} & \multirow[t]{2}{*}{$\begin{array}{l}\text { Pendidikan } \\
\text { masyarakat }\end{array}$} & $\begin{array}{l}\text { Pelatihan pembuatan kerajinan tangan } \\
\text { berupa bross jilbab dari kancing baju, } \\
\text { membuat bunga dari kain flanel, perca, } \\
\text { botol bekas dan sedotan, membuat gelang } \\
\text { dari tali kur, dan membuat tempat tissu } \\
\text { dari stik es krim }\end{array}$ & $8 \times 2$ jam & 9 \\
\hline & & $\begin{array}{l}\text { Penyuluhan dan pemeriksaan lingkungan } \\
\text { agar bersih dari sampah guna pencegahan } \\
\text { DBD, .dalam rangka melindungi warga } \\
\text { dari berbagai penyakit di musim hujan }\end{array}$ & $4 \times 2$ jam & 6 \\
\hline & & $\begin{array}{l}\text { Penyuluhan cuci tangan, gosok gigi dan } \\
\text { perilaku hidup bersih dan sehat (PHBS) }\end{array}$ & $2 \times 2$ jam & 6 \\
\hline \multirow[t]{4}{*}{2} & Difusi iptek & $\begin{array}{l}\text { Pelatihan pembuatan tepung dan berbagai } \\
\text { makanan dan minuman dari bahan Beras } \\
\text { Hitam }\end{array}$ & $8 \times 2$ jam & 9 \\
\hline & & $\begin{array}{l}\text { Pelatihan pembuatan masker wajah } \\
\text { berbahan dasar beras hitam }\end{array}$ & $4 \times 2$ jam & 6 \\
\hline & & $\begin{array}{l}\text { Pelatihan membuat olahan makanan } \\
\text { berbahan dasar mocaf. Makanan yang } \\
\text { dibuat terdiri dari donat, putu ayu, banana } \\
\text { kres, crispy pisang, botecok (bola telo } \\
\text { cokelat) }\end{array}$ & $6 \times 2$ jam & 12 \\
\hline & & $\begin{array}{l}\text { Pendampingan pembuatan pupuk cair } \\
\text { dari kencing ternak kelinci }\end{array}$ & $4 \times 2$ jam & 9 \\
\hline \multirow[t]{3}{*}{3} & \multirow[t]{3}{*}{ Praktek } & Pelatihan hadroh & $4 \times 2$ jam & 3 \\
\hline & & Plangisasi Desa Wisata & $6 \times 2$ jam & 9 \\
\hline & & Pembuatan Perpustakaan Masjid & $4 \times 2$ jam & 9 \\
\hline
\end{tabular}

\section{HASIL, PEMBAHASAN DAN DAMPAK}

\section{Profil warga Dusun Gulo, Nangsri dan Candi}

Budaya yang kental selalu melekat di setiap dusun terkait bidang segi keagamaan dan kesenian. Kampung Karang monggang dan Candi lebih kental dengan keagamaan sedangkan kampung dowi dan derso kental dengan budaya seni. Masing-masing dusun mempunyai ciri khas dalam pelaksanaan budayanya. Kegiatan keagamaan yang dilakukan seperti tabligh akbar, sedangkan kegiatan seni seperti wayang 
Berbagai potensi daerah menyebabkan Pundong terkenal dengan wisata kuliner "mie-des" dan berbagai usaha masyarakat yang sudah mulai dikenal terutama usaha makanan ringan. Hasil usaha mayoritas warga Pundong dalam hal mengelola home industri, seperti pengolahan singkong yang dijadikan tepung aci, miedes, mie pentil, abangan, criping tahu dan kerupuk.

Adapun hasil pertanian yang sangat diunggulkan adalah beras hitam dikarenakan potensi pertaniannya sangat baik maka usaha pemupukannya juga selalu dijaga dengan menggunakan pupuk organik hasil olahan warga berupa pupuk organik cair dari kencing kelinci.

\section{Pelaksanaan Program Kerja}

Beberapa program kerja yang telah berhasil dilaksanakan dalam upaya pemberdayaan ummat KKN di dusun Gulon, Dusun Nangsri dan Dusun Candi Kecamatan Pundong, Kabupaten Bantul sejak pada bulan Januari 2017 selama satu bulan penuh di antaranya adalah :

a. Bimbingan Belajar

Program bimbel ini dilaksanakan dengan sasaran anak sekolah yang mengalami kesulitan dalam memahami pelajaran, membantu mengerjakan PR, dan mengerjakan soalsoal latihan. Materi bimbel yang diberikan berupa IPA, Bahasa Inggris dan Matematika.

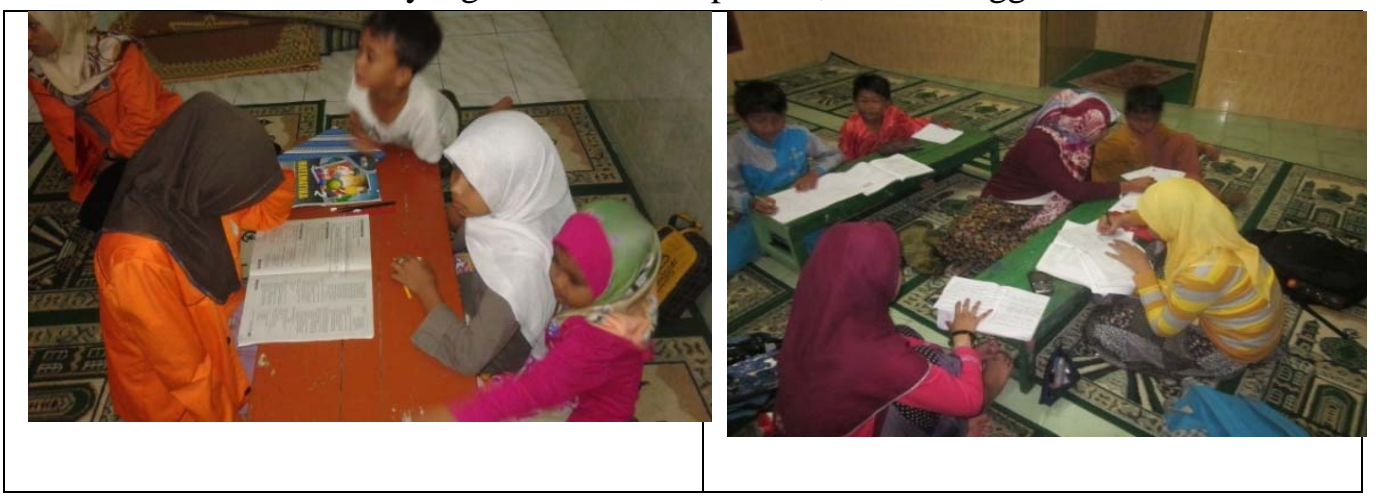

b. Berbagai Penyuluhan

Program kegiatan pertama adalah penyuluhan dan pemeriksaan lingkungan agar bersih dari sampah guna pencegahan DBD, dalam rangka melindungi warga dari berbagai penyakit di musim hujan. Program ini tepat dilaksanakan karena elaksanaan kegiatan di kecamatan Pundong bertepatan dengan musim hujan yang biasanya sering muncul penyakit yang berkaitan dengan lingkungan yang tidak bersih.

Bagi remaja diberikan Penyuluhan kesehatan reproduksi yang bertujuan untuk menambah pengetahuan pentingnya menjaga kebersihan dan kesehatan reproduksi serta mengendalikan pergaulan bebas untuk menghidari penularan penyakit seksual. 


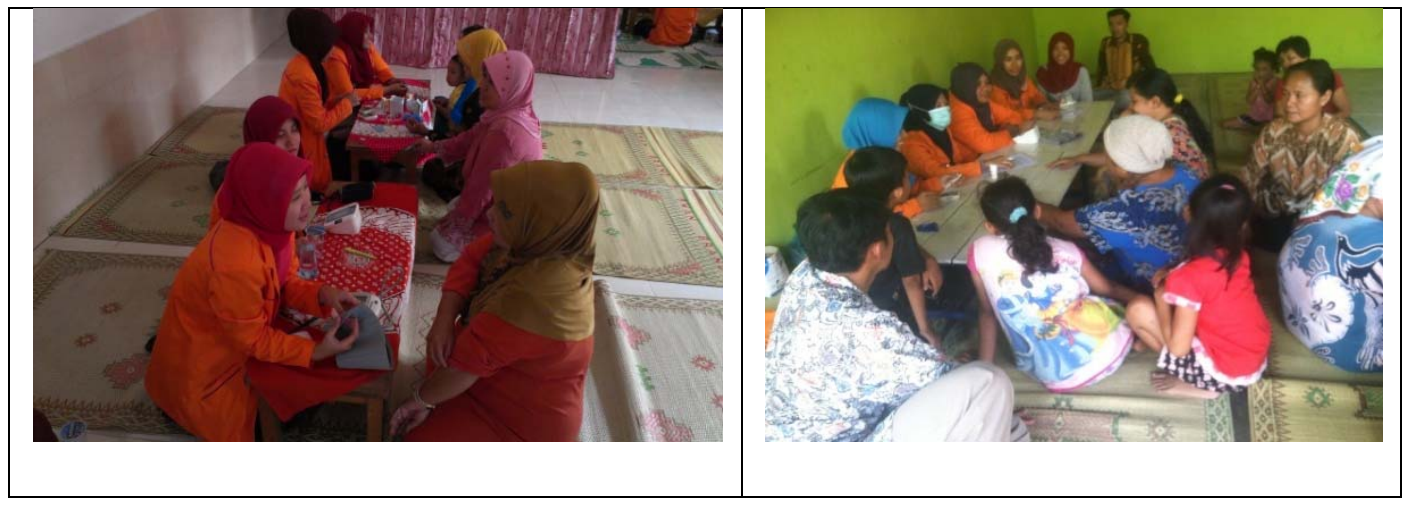

Selanjutnya dilaksanakan penyuluhan cuci tangan, gosok gigi dan perilaku hidup bersih dan sehat (PHBS) terutama diberikan kepada sasaran anak-anak untuk memberi penanaman perilaku sehat sejak dini sehingga akan terbiasa melakukannya setelah dewasa.

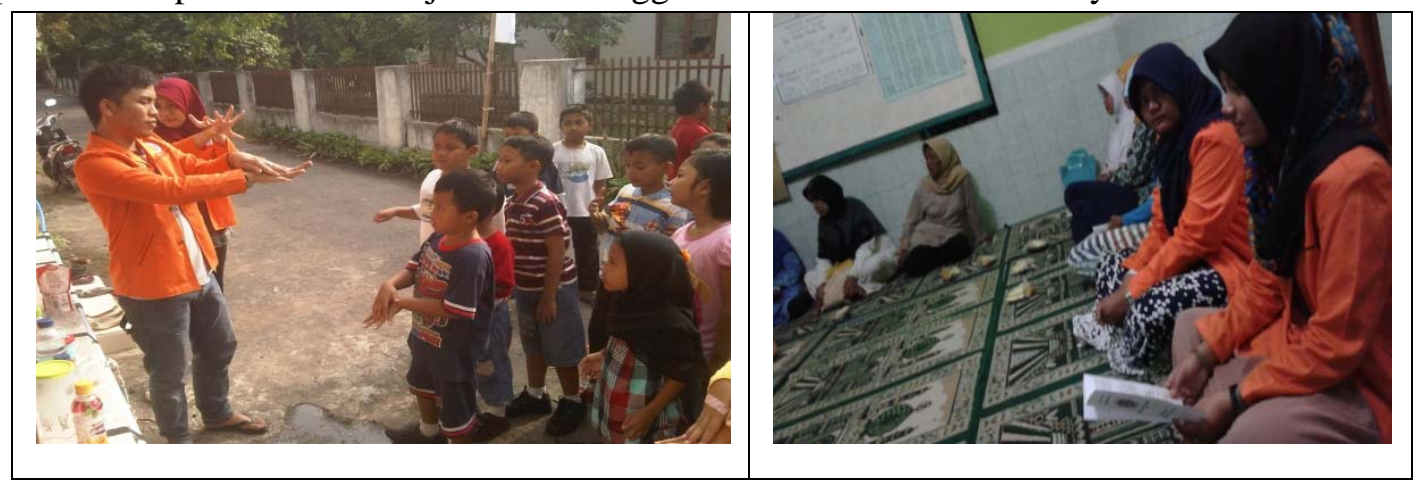

c. Berbagai Pelatihan

Beberapa pelatihan yang dilaksanakan selama kegiatan tersebut berupa : pelatihan pembuatan kerajinan tangan bross jilbab dari bahan baku kancing baju menjadi bebrbagai macam bentuk bross yang menarik.

Kemudian dengan memanfaatkan bahan-bahan tidak terpakai juga diberikan pelatihan kepada remaj dan anak-anak antarlain : membuat bunga dari berbagai macam barang bekas seperti kain flanel, perca, botol bekas dan sedotan.

Program ketrampilan lainnya adalah membuat gelang dari tali kur, dan membuat tempat tissu dari stik es krim dengan berbagai kreasi sesuai dengan inovasi masing-masing peserta. 


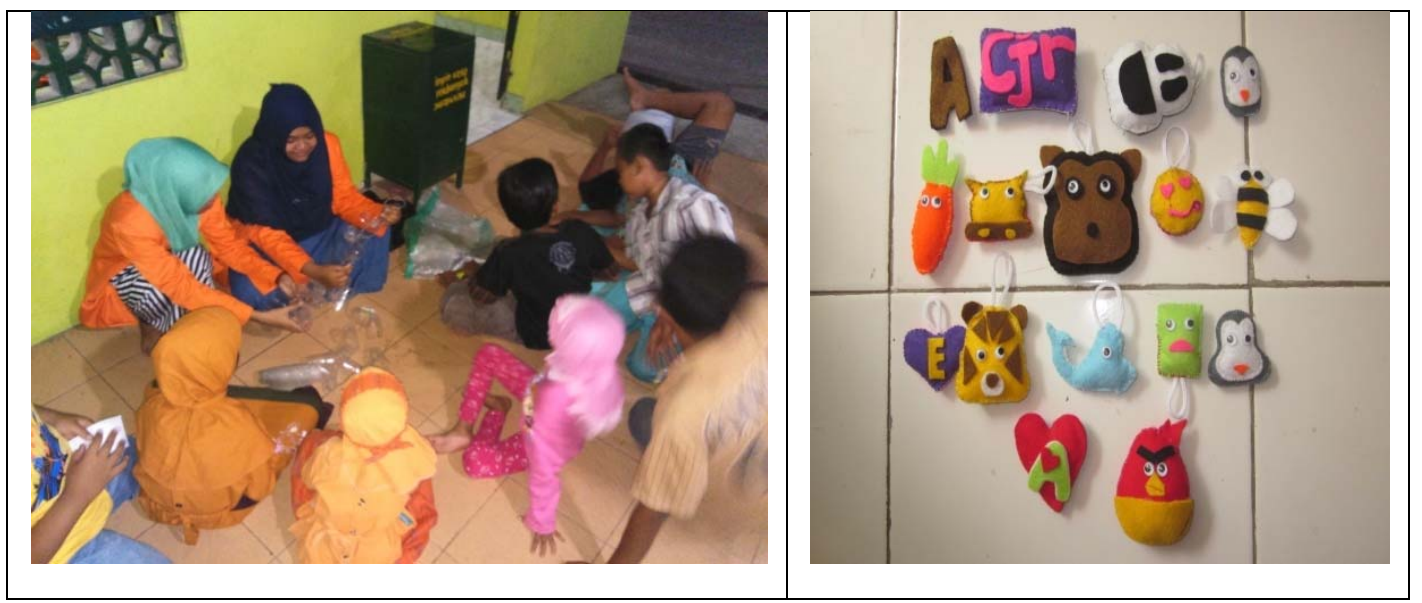

Kepada kelompok ibu-ibu pada setiap pertemuan rutin setiap seminggu sekali diberikan Pelatihan pembuatan tepung dan berbagai makanan dan minuman dari bahan Beras Hitam sebagai tindak lanjut dari potensi wilayah yang melimpah dari hasil panen yang berhasil dan berlimpah. Beras Hitam juga bisa dimanfaatkan sebagai masker yang sangat baik hasilnya, antusias warga pada pelatihan terutama dari remaja karena banyak yang memiliki masalah dengan kulit wajah.

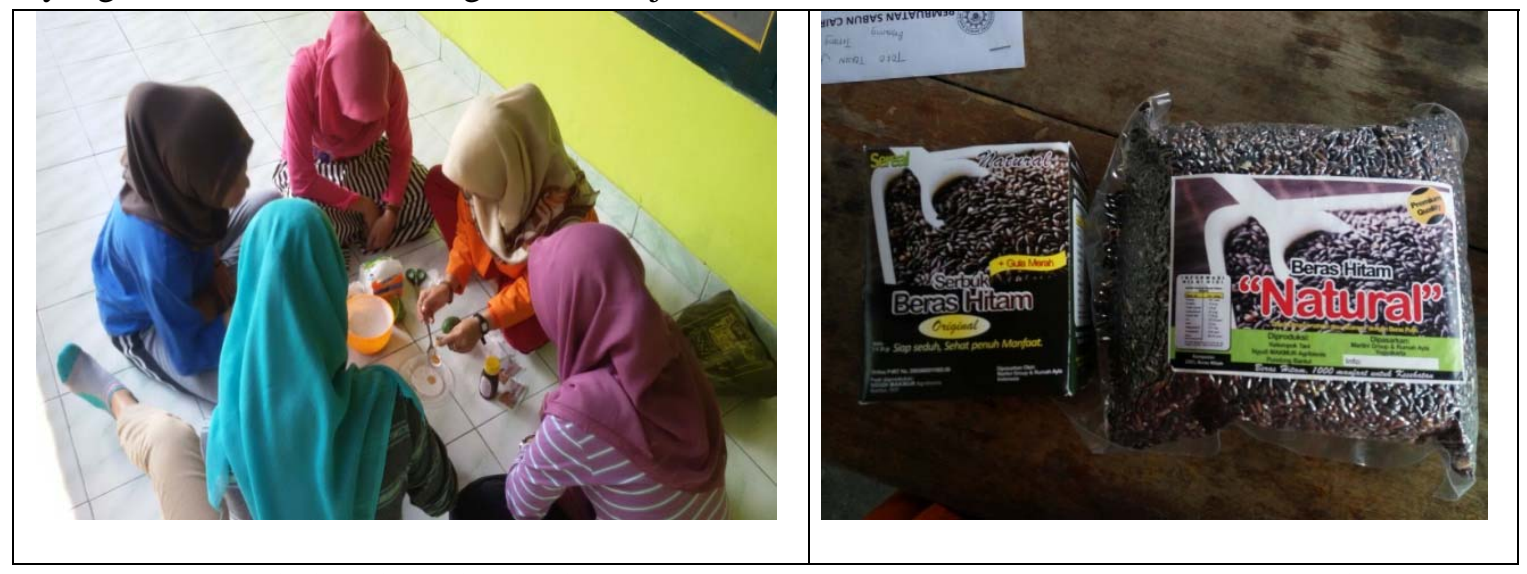

Sebagai tindak lanjut kerjasama LPM UAD dengan MPM PP Muhammadiyah, maka dilaksanakan pula program Pelatihan membuat olahan makanan berbahan dasar mocaf. Tepung Mocaf adalah hasil produksi dari 13 KWT di Gunung Kidul yang telah berhasil membuat tepung alternatif pengganti terigu sebagai hasil dari pendampingan LPM dan MPM selam 3 tahun. Olahan makanan dibuat menjadi 4 resep terdiri dari donat, putu ayu, crispy pisang, botecok (bola telo cokelat) 
Diterbitkan oleh Lembaga Pengabdian kepada Masyarakat Universitas Ahmad Dahlan Yogyakarta
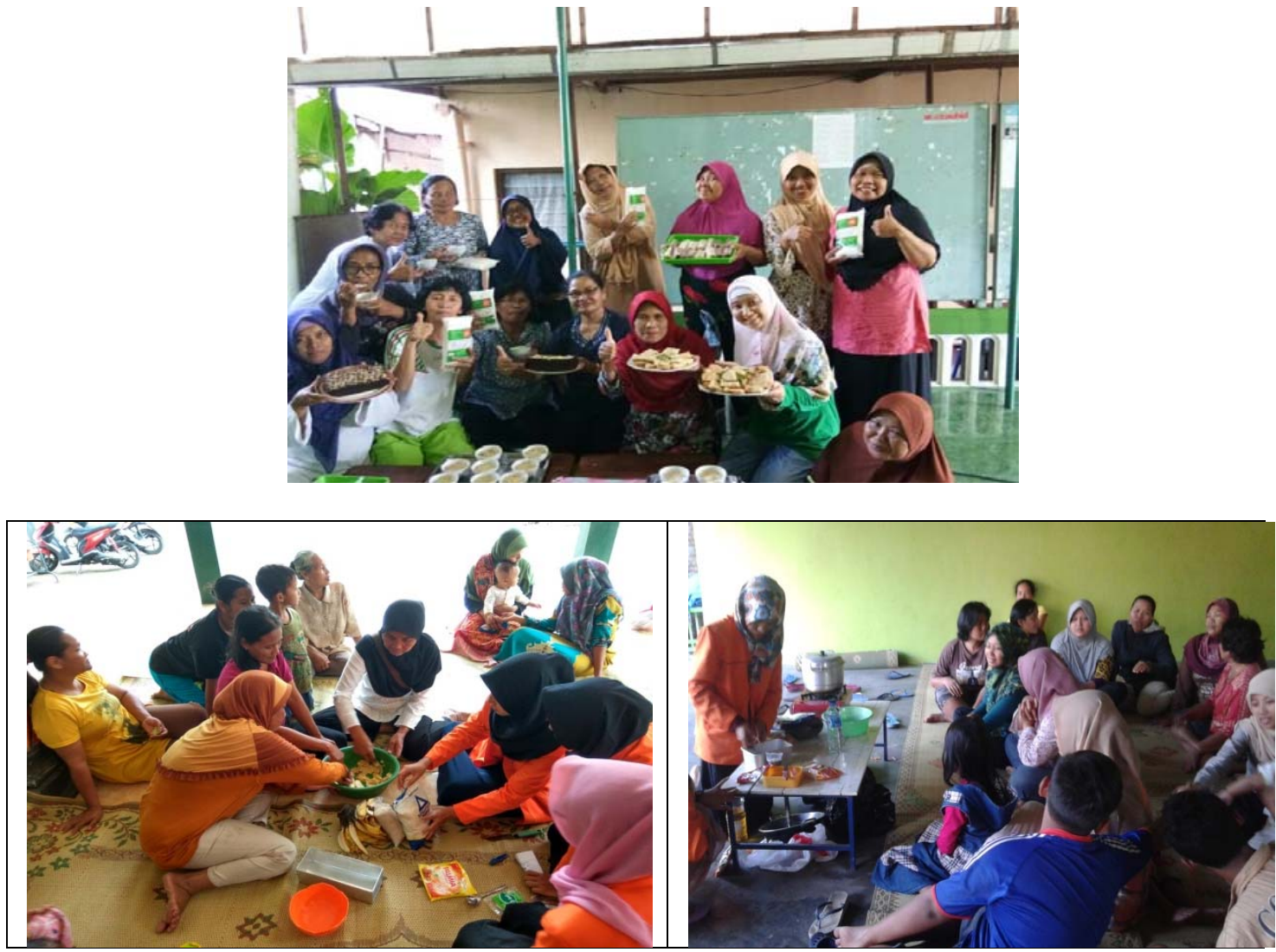

Pelatihan yang terakhir terkait dengan peternak kelinci, dimana kotoran kelinci berupa kencing kelinci yang sangat menyengatbaunya sehingga mengganggu namun ternyat bermanfaat karena dapat diolah menjadi pupuk cair. Tentu saja pupuk ini sangat aman digunakan petani karena tidak ada unsur kimiawi di dalamnya.

Program pembuatan perpustakaan masjid dilaksanakan dalam rangka meningkatkan minat baca anak-anak TPA yang kelak akan menjadi generasi unggul dengan terbukanya jendela dunia melalui membaca.

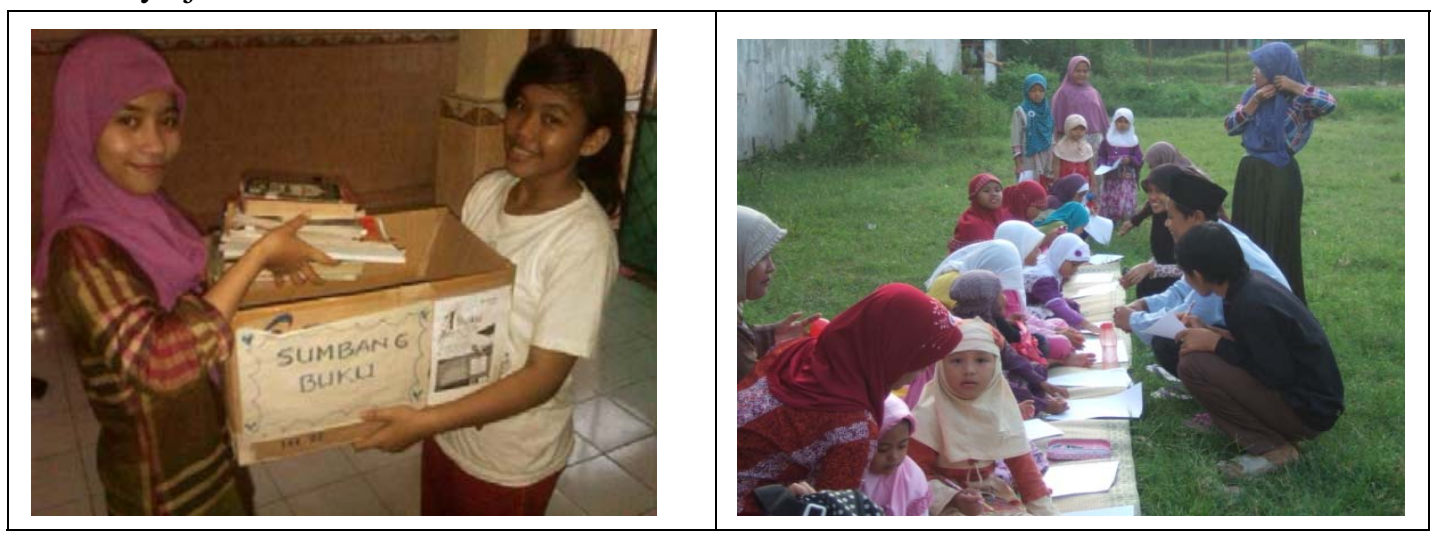


Dari uraian pelaksanaan kegiatan tersebut terlihat bahwa program PPM di Dusun Gulon, Dusun Nangsri dan Dusun Candi Kecamatan Pundong, Kabupaten Bantul diharapkan dapat tercapainya tujuan kegiatan ini: 1) tercipta kesadaran ummat tentang hidup bersih dan sehat, 2) peningkatan pengetahuan warga Pundong tentang pemanfaatan potensi wilayah, 3) masyarakat terampil dalam berbagai program pemanfaat bahan-bahan tidak terpakai, 4) tersedianya taman bacaan di masjid untuk mencerdaskan ummat.

\section{KESIMPULAN}

Pelaksanaan Kegiatan PPM di Dusun Gulon, Dusun Nangsri dan Dusun Candi dapat terlaksanan dengan baik dan lancar berkat antusias warga yang sangat mendukung terlaksananya program dan peran serta mahasiswa pada seluruh kegiatan PPM sejak awal hingga akhir pelaksanaan program PPM.

\section{DAFTAR PUSTAKA}

Laporan KKN Reguler periode LXI Tahun Akademik 2016/2017 di Dusun Gulon, Dusun Nangsri dan Dusun Kecamatan Pundong, Kabupaten Bantul. 